\title{
Effect of Foliar and Soil Application of Micro Nutrients and Use of PSB on Productivity and Water Use Efficiency of Chickpea under Rainfed Condition
}

\section{Pradeep Kumar*, Rajeev Kumar, Brij Mohan, Sandeep Kumar Yadav, Shailendra Singh and Bhagwan Singh}

\author{
Department of Agronomy, Narendra Deva University of Agriculture and Technology \\ Kumarganj Faizabad (U.P.), India \\ *Corresponding author
}

\section{A B S T R A C T}

\begin{tabular}{|l} 
K e y w o r d s \\
Chickpea, Foliar \\
application, Water \\
use efficiency, \\
B: C ratio, \\
Basal application. \\
\hline Article Info \\
\hline $\begin{array}{l}\text { Accepted: } \\
\text { 23 June 2017 } \\
\text { Available Online: } \\
\text { 10 August } 2017\end{array}$
\end{tabular}

\section{Introduction}

Pulses are the important source of dietary protein and have unique properties of maintaining and restoring soil fertility through biological nitrogen fixation as well as conserving and improving the soil physical properties by virtue of their deep root system and leaf fall. Pulses are grown on nearly 22.99 million hectares of the area with production of 17.58 million tonnes in India (Anonymous 2013). India is the largest producer of chickpea contributing about 65 per cent of world chickpea production. The important chickpea growing states in India are Madhya Pradesh, Rajasthan, Uttar Pradesh, Maharashtra, Karnataka and Haryana. It is mostly cultivated in rabi season as its growth is promoted by cool climate and morning dew. In India, chickpea occupies an area of 7.92 million hectares with a production of 7.06 million tonnes (Anonymous, 2013), contributing 34.7 percent to the total area and 48.4 per cent to the total production of pulses in the country. The average productivity of chickpea in India is about $885 \mathrm{~kg} \mathrm{ha}^{-1}$. In Uttar Pradesh, chickpea occupies an area of 0.55 million hectares with a production of 0.56 million tonnes, with an average productivity of $1010 \mathrm{~kg} \mathrm{ha}^{-1}$. The crop growth and yield performance of chickpea is influenced by a number of factor like soil, climate, manure and fertilizers under intensive system of cultivation is identical as 
the single most important factor controlling the yield optimization. Since farmyard manure or compost alone cannot supply the entire nutrient requirement of the crop to adequate growth performance throughout the life cycle, the plants often suffer from hidden hunger due to deficiency of major and minor plant nutrients like nitrogen $(\mathrm{N})$, phosphorus (P) and potash (K). Among all the major plant nutrients $\mathrm{P}$ plays an important role under rainfed condition, moisture stress, upland condition. Since legume is heavy feeder of phosphorus, therefore, application of phosphatic fertilizer to chickpea promotes the growth, nodulation and the yield. Phosphorus also imparts hardiness to shoot, improves the quality and regulates the photosynthesis and covers other physico- biochemical process. Most of the phosphorus present in the soil is unavailable to plants which are made available through the activities of efficient micro-organism like bacteria, fungi and even cyanobacteria with production of organic acid and increasing phosphatase enzyme activity. Methods of fertilization application are a nonmonetary input which influences growth and consequently crop yields. Foliar nutrient is recognized as an important method of fertilizer application, since foliar nutrients usually penetrate the leaf cuticle or stomata and enter the cells facilitating easy and rapid utilization of nutrients by the crop (Laha and Nadanassababady, 2003). Therefore keeping these in view an investigation was carried out to study effect of foliar and soil application of micro nutrients and use of PSB on productivity and water use efficiency of chickpea under rainfed condition.

\section{Materials and Methods}

The field experiment was conducted at Agronomy research Farm of NDUA\&T, Faizabad Uttar Pradesh during the winter (rabi) season of 2012-13 and 2013-14. The soil was silt loam with $8.5 \mathrm{pH} 0.32$ organic carbon, $0.53 \mathrm{EC}, 175.40 \mathrm{~kg}$ available $\mathrm{N}, 15.25$ $\mathrm{kg}$ available $\mathrm{P}_{2} \mathrm{O}_{5}$ and $238.0 \mathrm{~kg}$ available $\mathrm{K}_{2} \mathrm{O}$ $\mathrm{ha}^{-1}$ in upper $30 \mathrm{~cm}$ soil depth. Twelve treatments combinations comprising Control $\left(\mathrm{T}_{1}\right), 100 \mathrm{~kg}$ DAP as basal $\left(\mathrm{T}_{2}\right), \mathrm{T}_{1}+3$ water sprays@800 lit. ha ${ }^{-1}$ at 25, 45 and 65 DAS $\left(\mathrm{T}_{3}\right), 50 \mathrm{~kg} \mathrm{DAP} \mathrm{ha}^{-1}$ as basal + $50 \mathrm{~kg}$ DAP as foliar in two splits at $25 \& 45 \mathrm{DAS}\left(\mathrm{T}_{4}\right), 100$ $\mathrm{kg}$ DAP ha ${ }^{-1}$ as basal + $20 \mathrm{~kg} \mathrm{ZnSO}_{4} \mathrm{ha}^{-1}$ as basal $\left(\mathrm{T}_{5}\right), 100 \mathrm{~kg}$ DAP ha ${ }^{-1}$ as basal +2 spraying of $2 \% \mathrm{ZnSO}_{4} \mathrm{ha}^{-1}$ at $25 \& 45 \mathrm{DAS}$ $\left(\mathrm{T}_{6}\right), 100 \mathrm{~kg}$ DAP $\mathrm{ha}^{-1}$ as basal $+40 \mathrm{~kg}$ sulphur ha ${ }^{-1}$ as basal $\left(\mathrm{T}_{7}\right), 100 \mathrm{~kg}^{\mathrm{DAP} \mathrm{ha}}{ }^{-1}$ as basal +2 spraying of $2 \%$ sulphur as foliar at $25 \& 45$ DAS $\left(\mathrm{T}_{8}\right), 100 \mathrm{~kg}$ DAP ha ${ }^{-1}$ as basal $+5 \mathrm{~kg}$ borax $\mathrm{ha}^{-1}$ as basal $\left(\mathrm{T}_{9}\right), 100 \mathrm{~kg}$ DAP $\mathrm{ha}^{-1}$ as basal +2 spraying of $0.5 \%$ Borax $^{-1}$ as foliar at $25 \& 45$ DAS $\left(\mathrm{T}_{10}\right), 50 \mathrm{~kg}$ DAP $\mathrm{ha}^{-1}+$ PSB $\left(\mathrm{T}_{11}\right), 75 \mathrm{~kg} \mathrm{DAP} \mathrm{ha}{ }^{-1}+$ PSB $\left(\mathrm{T}_{12}\right)$ were tested in randomized block design (RBD) with three replications. The seeds of chickpea var.PG-186 were sown in plots of $4.5 \times 5.0 \mathrm{~m}$ size at a spacing of $45 \times 10 \mathrm{~cm}$ in last fortnight of October during both the seasons. The sources of nitrogen, phosphorus, potassium, sulphur and boron were urea, diammonium phosphate, muriate of potash, elemental sulphur and borax, zinc sulphate respectively. All nutrients applied at time of sowing. All recommended cultural practices were adopted to raise the crop. Observation on various growth and yield related attributes were recorded, using standard procedures. The data recorded in respect to different observations were analyzed as per standard statistical procedure. The data thus collected was subjected to analysis of variance using the method proposed by Panse and Sukhatme (1978). The consumptive use of crop was calculated with standard methodology by estimating $(\mathrm{cu}=\mathrm{Kc} \times$ PET $)$. PET was estimated by using Modified Penman method, Doorenbos and Pruitt (1975). The Water Use efficiency was calculated by dividing the grain yield $(\mathrm{kg} / \mathrm{ha})$ to cumulative rainfall $(\mathrm{mm})$ from sowing to harvest. WUE $(\mathrm{kg} / \mathrm{ha}$ 
$\mathrm{mm}^{-1}$ ) indicates yield attained by a treatment per millimetre of rain water received during the cropping period.

\section{Results and Discussion}

\section{Growth and yield attributes}

The various growth and yield attributing characters of chickpea were significantly influenced by treatments. The treatment, $\mathrm{T}_{7}$ was found superior to other treatments i.e. control, sprayed and unsprayed treatments

(Table1). two spraying of $2 \% \mathrm{ZnSO}_{4} \mathrm{ha}^{-1}$ at 25 and 45 DAS along with $100 \mathrm{~kg}$ DAP ha ${ }^{-1}$ as basal $\left(\mathrm{T}_{6}\right)$ appreciably improved growth and yield attributing parameters like plant height, number of pods plant ${ }^{-1}$, number of seeds $\operatorname{pod}^{-1}$, seed weight plant ${ }^{-1}, 100$ seed weight, seed yield and yield straw. However, harvest index did not show significant variation. Spraying of $\mathrm{ZnSO}_{4}$ at 25 and 45 DAS stage influenced the vigour of the plant through effective absorption of nutrients at critical stages, resulting in enhanced physiological activity and increased dry matter production. Increase in growth and yield attributing characters due to foliar application of $\mathrm{ZnSO}_{4}$ at critical stage could be ascribed to the overall improvement in plant growth, vigour and production of photosynthates owing to increased availability, absorption and translocation of nutrient in plants. Sarkar et al., (1999) and Amanullah et al., (2010) also reported that in growth and yield attributing characters were associated with enhancement of zinc sulphate level in plant due to foliar application of $\mathrm{ZnSO}_{4}$.

\section{Grain and straw yields as influenced by various treatments}

The grain and straw yields were significantly influenced by different treatments in both of the years and also when pooled (Table 1). The highest grain yield was recorded by $\mathrm{T}_{6}$ during individual years 2012-13, 2013-14 and pooled (22.42, 23.01 and $22.72 \mathrm{q} \mathrm{ha}^{-1}$, respectively) which was statistically at par with $\mathrm{T}_{3}$ and $\mathrm{T}_{4}$ and significantly superior over the rest of treatments $\mathrm{T}_{1}$ (control) produced lowest seed yield of chickpea. The straw yield was also significantly influenced by various treatments during 2012-13, 2013-14, similar findings were recorded by Sethi et al., (2016) and in pooled and showed the similar trends as grain yields, similar findings were recorded by Kumar et al., (2015). However, treatment $\mathrm{T}_{6}$ showed better performance in terms of grain yield, straw yield, WUE and $B$ : $C$ ratio as compared to other. Further monthly rainfall distribution pattern during both the crop season (2012-13 and 2013-14) showed that comparatively higher rainfall was received during January at the time vegetative growth stage, however very limited rainfall was received during sowing and branching stage.

This indicates that higher values of grain yield, straw yield, WUE and $\mathrm{B}$ : $\mathrm{C}$ ratio in $\mathrm{T}_{6}$ is due to foliar application of $\mathrm{ZnSO}_{4}$ which contributed significantly in increasing the grain yield and other yield related parameters of the crop under moisture stress condition during critical growth stages (Figure 1) under normal range of temperature for the growth of chickpea (Figure 2). Foliar application Zinc Sulphate produced variation in biomass and grain yield. Zinc Sulphate (2\%) when sprayed during 25 and 45 DAS along with $100 \mathrm{~kg}$ DAP as basal $\left(\mathrm{T}_{6}\right)$ also gave significantly higher number of pods than control treatments in both the years and also in pooled data (Table1). This treatment produced 77.97 numbers of pod plant ${ }^{-1}$ over the rest of treatments. It appears that nutrient supplied through foliar application of $\mathrm{ZnSO}_{4}$ at critical and vegetative stages are effective absorbed by the plants, assimilated and translocated more efficiently to the developing pods for proper filling which reflected in higher values of yield attributes and resulted in higher seed yield. 
Table.1 Effect of various treatments on yield and yield attributes of chickpea

\begin{tabular}{|c|c|c|c|c|c|c|c|c|c|}
\hline Treatments & $\begin{array}{l}\text { Number of } \\
\text { pod plant }^{-1}\end{array}$ & $\begin{array}{l}\text { Number of } \\
\text { seed pod }^{-1}\end{array}$ & $\begin{array}{l}\text { Seed weight } \\
\text { plant }^{-1}(\mathrm{~g})\end{array}$ & $\begin{array}{l}\text { Test weight } \\
\text { (g) }\end{array}$ & $\begin{array}{c}\text { Seed yield }(q \\
\left.\text { ha }^{-1}\right)\end{array}$ & $\begin{array}{l}\text { Straw yield } \\
\quad\left(\mathbf{q} \mathbf{h a}^{-1}\right)\end{array}$ & $\begin{array}{c}\text { Harvest } \\
\text { index }(\%)\end{array}$ & $\begin{array}{l}\text { Consumptive } \\
\text { use (mm) }\end{array}$ & $\begin{array}{c}\text { Water use efficiency } \\
\left(\mathrm{kg} / \mathrm{ha} \mathrm{mm}^{-1}\right)\end{array}$ \\
\hline $\mathrm{T}_{1}$ & 63.43 & 1.35 & 13.07 & 12.79 & 16.29 & 25.28 & 39.20 & 91.18 & 18.30 \\
\hline $\mathrm{T}_{2}$ & 67.60 & 1.61 & 16.64 & 15.27 & 19.45 & 30.23 & 39.15 & 108.86 & 22.15 \\
\hline $\mathrm{T}_{3}$ & 73.16 & 1.75 & 21.09 & 16.53 & 21.05 & 32.05 & 39.93 & 117.77 & 23.97 \\
\hline $\mathrm{T}_{4}$ & 76.86 & 1.86 & 25.41 & 17.59 & 22.40 & 33.16 & 40.32 & 125.35 & 25.52 \\
\hline $\mathrm{T}_{5}$ & 72.47 & 1.73 & 20.50 & 16.36 & 20.85 & 31.37 & 39.84 & 116.66 & 23.75 \\
\hline $\mathrm{T}_{6}$ & 77.97 & 1.88 & 26.52 & 17.84 & 22.72 & 34.14 & 39.78 & 127.14 & 25.88 \\
\hline $\mathrm{T}_{7}$ & 71.43 & 1.71 & 19.62 & 16.14 & 20.55 & 31.05 & 39.35 & 115.00 & 23.41 \\
\hline $\mathrm{T}_{8}$ & 70.56 & 1.68 & 18.91 & 15.94 & 20.30 & 30.78 & 39.74 & 113.59 & 23.12 \\
\hline $\mathrm{T}_{9}$ & 67.78 & 1.62 & 16.76 & 15.31 & 19.50 & 30.15 & 39.28 & 109.08 & 22.21 \\
\hline $\mathrm{T}_{10}$ & 72.13 & 1.72 & 20.20 & 16.39 & 20.75 & 31.19 & 39.20 & 116.11 & 23.63 \\
\hline $\mathrm{T}_{11}$ & 65.11 & 1.52 & 13.86 & 14.37 & 18.30 & 29.11 & 39.15 & 102.40 & 20.84 \\
\hline $\mathrm{T}_{12}$ & 67.95 & 1.62 & 16.89 & 15.35 & 19.55 & 30.13 & 39.93 & 109.37 & 22.27 \\
\hline SEm \pm & 2.58 & 0.06 & 0.92 & 0.53 & 0.59 & 0.95 & 1.40 & 4.69 & 0.98 \\
\hline $\mathrm{CD}$ at $5 \%$ & 7.55 & 0.17 & 2.70 & 1.57 & 1.74 & 2.78 & NS & 13.76 & 2.89 \\
\hline
\end{tabular}

Table. 2 Cost of cultivation, gross return, net return and benefit-cost ratio of chickpea

\begin{tabular}{|c|c|c|c|c|}
\hline Treatment & Cost of cultivation ( $\left(₹ \mathrm{ha}^{-1}\right)$ & Gross return (₹ ha $\left.^{-1}\right)$ & Net return $\left(₹\right.$ ha $\left.^{-1}\right)$ & Benefit : cost ratio \\
\hline $\mathbf{T}_{1}$ & 17866 & 72273 & 47904 & 2.69 \\
\hline $\mathbf{T}_{2}$ & 20669 & 86191 & 59237 & 2.87 \\
\hline $\mathbf{T}_{3}$ & 21131 & 93159 & 65291 & 3.10 \\
\hline $\mathbf{T}_{4}$ & 20900 & 99066 & 71124 & 3.41 \\
\hline $\mathbf{T}_{5}$ & 21824 & 92288 & 63770 & 2.93 \\
\hline $\mathbf{T}_{6}$ & 21016 & 100567 & 72461 & 3.45 \\
\hline $\mathbf{T}_{7}$ & 22769 & 91037 & 61607 & 2.71 \\
\hline $\mathbf{T}_{8}$ & 21005 & 89868 & 62355 & 2.97 \\
\hline $\mathbf{T}_{9}$ & 20997 & 86397 & 59062 & 2.82 \\
\hline $\mathbf{T}_{10}$ & 20933 & 91871 & 64302 & 3.08 \\
\hline $\mathbf{T}_{11}$ & 19724 & 81175 & 55477 & 2.82 \\
\hline $\mathbf{T}_{12}$ & 20369 & 86608 & 59876 & 2.94 \\
\hline
\end{tabular}


Fig.1 Monthly rainfall during crop season (Oct-Mar) of 2012-13 \& 2013-14

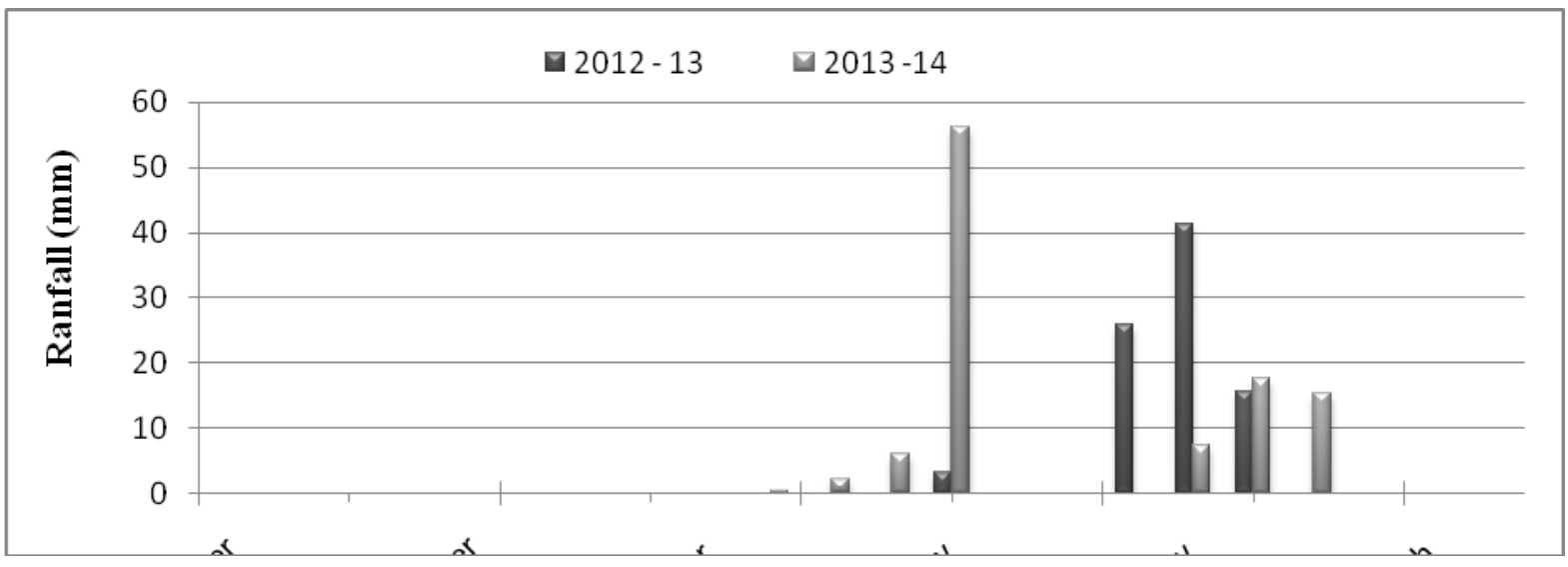

Fig.2 Monthly maximum and minimum temperature $\left({ }^{0} \mathrm{C}\right)$ during the crop season (Oct-Mar) 2012-13 \& 2013-13

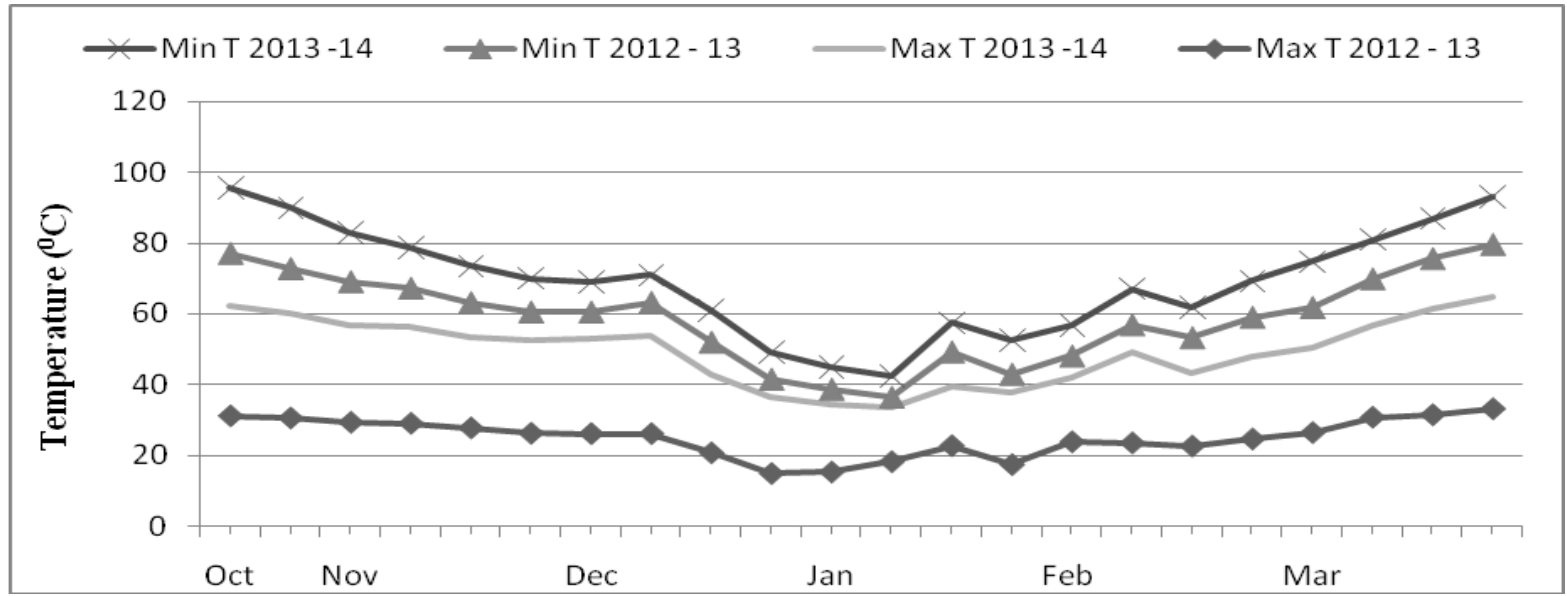

Foliar application $\mathrm{ZnSO}_{4}$ during 25 and 45 DAS also enhances photosynthetic activity in effective leaves and turn supplied the developing pods with current photosynthates and resulted higher yield. Highest straw yield of $34.14 \mathrm{q} / \mathrm{ha}$ was also recorded by the treatment $\mathrm{T}_{6}$. Namvar et al., (2011) reported that $\mathrm{P}$ application increase in yield attributes and ultimately seed yield of chickpea. Supplementation of adequate $\mathrm{N}$ for crops can increase their growth and development. The increase in seed yield with phosphorus and $\mathrm{ZnSO}_{4}$ application was due to (i) increase in source capacity like plant height, number of branches plant ${ }^{-1}$ and number of leaves plant ${ }^{-1}$ as well as sink capacity like, number of pods plant $^{-1}$, number of seeds pod ${ }^{-1}$ and test weight (ii) better utilization of photosynthates towards sink due to increase in translocation from source to sink. The result is in conformity with the finding of Singh et al., (2014), Ganga et al., (2014), Pathak et al., (2012), Singh and anubhuti (2011), Kuttimani and Velayutham, (2011) and Singh et al., (2009).

\section{Consumptive use and water use efficiency}

It is clear from the data given in Table 1 consumptive use of water was significant affected by various treatments. $\mathrm{T}_{6}$ treatments $\left(100 \mathrm{~kg} \mathrm{DAP} \mathrm{ha}^{-1}\right.$ as basal +2 spraying of 2 
$\% \mathrm{ZnSO}_{4} \mathrm{ha}^{-1}$ at $\left.25 \& 45 \mathrm{DAS}\right)$ being at par with $\mathrm{T}_{3}, \mathrm{~T}_{4}, \mathrm{~T}_{5}, \mathrm{~T}_{7}$ and $\mathrm{T}_{10}$ registered significantly higher consumptive use of water over remaining treatments.

The water use efficiency of chickpea was significantly affected by various treatments. $\mathrm{T}_{6}$ treatments $\left(100 \mathrm{~kg} \mathrm{DAP} \mathrm{ha}^{-1}\right.$ as basal +2 spraying of $2 \% \mathrm{ZnSO}_{4} \mathrm{ha}^{-1}$ at $25 \& 45$ DAS) being at par with $\mathrm{T}_{3}, \mathrm{~T}_{4}, \mathrm{~T}_{5}, \mathrm{~T}_{7}$ and $\mathrm{T}_{10}$ proved to be significantly superior over remaining treatments. Similar finding were also reported by Upanal et al., (2011).

\section{Economics}

Table 2 revealed the position of output and input in term of economics of production. The treatment wise cost of cultivation and their return revealed that the highest net return of ' 73212 was observed in $\mathrm{T}_{6}$ treatment $(100 \mathrm{~kg}$ DAP ha ${ }^{-1}$ as basal +2 spraying of $2 \% \mathrm{ZnSO}_{4}$ $\mathrm{ha}^{-1}$ at $\left.25 \& 45 \mathrm{DAS}\right)$ gave highest $\mathrm{B}: \mathrm{C}$ ratio 3.45. However, lowest net return of ' 47904 was obtained in $\mathrm{T}_{1}$ with returns ${ }^{-1}$ invested of 2.69 similar trend has also been reported by various workers Kuttimani and Velayutham (2011) and Kumawat et al., (2013).

\section{References}

Aduloju, M.O., Mahamood, J. and Abayomi, Y.A. 2009. Evaluation of soybean genotype for adaptability to a southern Guinea savanna environment with and without $\mathrm{P}$ fertilizer application north central Nigeria. African J. Agric Res. 4 (6): 556-563.

Amanullah, Asif, M., Nawab, K.; Shah, Z.; Hassan, M.; Khan, A.Z.; Khalil, S.K.; Hussain, Z.; Tariq, M. and Rahman, H. 2010. Impact of planting density and $P$ fertilizer source on growth analysis of maize. Pak. J. Bot. 42(4):2349-2357.

Anonymous, 2013. The Hindu Survey of Indian Agriculture.
Chadha, K.L., 2003. Handbook of Horticulture, ICAR Publication New Delhi, pp. 52-64.

Chandrasekharan Srirama, M.V., 2009. Nutrient uptake, yield and quality of okra as influenced by sulphur in an entisol. Annals of Plant Soil Research. 11 (1): 19-21.

Doorenbos, J., and Pruilt, W.C. 1975. Guideline for predicting crop water requirements. Irr. And Drainage paper 24, FAO, Rome. 197p.

Ganga, N., Singh, R. K.; Singh, R. P.; Choudhary, S. K.; Upadhyay, P. K. 2014. Effect of potassium level and foliar application of nutrient on growth and yield of late sown chickpea (Cicer arietinum L.). Environment and Ecology, 32(1A): 273-275.

Gowswammy, N. N., 1986. In the forward to sulphur research and agriculture production India. (ed) H.L.S. Tondan, F.D.C.O. New Delhi. Pp.1-9.

Khan, M. U. S. H., Hashmi, M. A. N. M. I. M. N.; Dar, T. A. 2014. Use of $\mathrm{N}$ and $\mathrm{P}$ biofertilizers reduces inorganic phosphorus application and increases nutrient uptake, yield and seed quality of chickpea. Turkish J. of agric. And forestry, 38(1): 47-54.

Kumar, D., Arvadiya, L. K., Desai, K. L., Usadadiya, V. P. and Patel, A. M. 2015. Growth and yield of chickpea (Cicer arietinum 1.) as influenced by graded levels of fertilizers and biofertilizers. The Bioscan. 10(1): 335-338.

Kumar, V., Dwivedi, K.N. and Tiwari, D.D. 2009. Effect of phosphorus and iron on yield and mineral nutrition in chick pea. Ann. Pl. Soil Res. 11(1): 16-18.

Kumawat, P.K., Tiwari, R.C.; Golada, S.L.; Godara, A.S.; Garhwal, R.S. and Choudary, R. 2013. Effect of phosphorus sources, levels and biofertilizers on yield attributes, and economics of blackgram. Legume Res. 
36(1):70-73.

Kuttimani, R., and Velayutham, A. 2011. Foliar application of nutrients and growth regulators on yield and economics of greengram. Madras Agric. J. 98 (4-6): 141-143.

Laha, M.R., and Nadanassabady T. 2003. Foliar nutrition in crops-A Review. Agriculture Reviews, 24 (3): 229-234.

Mahamood, J., Abayomi and Aduloju, M.O. 2009. Comparative growth and grain yield responses of soybean genotype to phosphorous fertilizer application. African J. Biotech. 8 (6): 1030-1036.

Namvar, A., Sharifi, R.S. and Khandan, T. 2011. Growth analysis and yield of chickpea in relation to organic and inorganic nitrogen fertilization. Ekologija 57(3):97-108.

Panse, U.G., and Sukhatme, P.U. 1978. Statistical methods for agriculture workers. Indian Council Agric. Res., New Delhi.

Pathak, G. C., Gupta, B.; Pandey, N. 2012. Improving reproductive efficiency of chickpea by foliar application of zinc. Braz. J. Plant Physiol., 24(3): 173-180.

Sarkar, R.K., Chakraborty A. and Saha A.
1999. Effect of foliar application of potassium nitrate and calcium nitrate on groundnut. Indian j. of Agronomy 44 (4): 809-812.

Sethi, I. B., Sewhag, M., Kumar, P., and Jajoria, M. 2016.Yield performance of chickpea cultivars as influencedby sowing time and seed rate. The Bioscan. 11(1): 407-409.

Singh, B.J., Jyothi, C. N.; Ravichandra, K.; Gautam G. 2014. Effect of $\mathrm{Zn}$ and bio- inoculants on yield attributes of chickpea (Cicer arietinum). J. of Envir. And Ecology, 32(4): 1515- 1517.

Singh, Y. P., and Anbhuti S. 2011. Effect of sources of phosphorus and microbial inoculation on productivity, nutrient availability in soil and uptake of nutrients by chickpea (Cicer arietinum) grown on sandy loam soil. Indian J. of Agril. Sci., 81(9): 834-837.

Upanal, S., Guggari, A. K.; Babalad, H. B.; Sarwad, I. M.; Venkatesh, H. and Patil, A. B. 2011. Yield, economics and available soil moisture as influenced by soil types in different rabi crops under rainfed conditions. Karnataka J. Agric. Sci., 24 (3): 286 - 288.

\section{How to cite this article:}

Pradeep Kumar, Rajeev Kumar, Brij Mohan, Sandeep Kumar Yadav, Shailendra Singh and Bhagwan Singh. 2017. Effect of Foliar and Soil Application of Micro Nutrients and Use of PSB on Productivity and Water Use Efficiency of Chickpea under Rainfed Condition. Int.J.Curr.Microbiol.App.Sci. 6(8): 3074-3080. doi: https://doi.org/10.20546/ijcmas.2017.608.368 